\title{
The effect of dietary rumen degradable protein content on veal calf performance
}

\author{
L. Holtshausen and C.W. Cruywagen ${ }^{\#}$ \\ Department of Animal Sciences, University of Stellenbosch, Private Bag X1, Matieland 7602, South Africa.
}

\begin{abstract}
The objective of this study was to determine the undegradable dietary protein requirements of veal calves. Two experiments were carried out with Holstein bull calves from 3-10 days of age until slaughter at 20 weeks of age. Both experiments were divided into starter and finishing periods. Calves were offered starter pellets on an $a d$ lib. basis from seven days of age. Diets were formulated to be iso-nitrogenous and iso-caloric, and differed in undegradable dietary protein content. In Experiment 1 calves were randomly assigned to one of three dietary treatments containing low (LD), medium (MD) or high (HD) levels of rumen degradable protein. In Experiment 2 calves received a starter diet containing either a high or a low level of rumen degradable protein. At the end of the starter period animals from both treatment groups were re-assigned at random to finisher diets containing either low or high rumen degradable protein levels, resulting in four treatment combinations, viz. LL, LH, HL and HH. There were no treatment differences for feed intake, body weight gain or feed efficiency during the starter period of either experiment. During the finishing period (weeks 12-20) of Experiment 1, calves receiving the LD diet had higher average daily gains than calves receiving the HD treatment. Feed conversion ratio for the LD treatment was also better than for the other two treatments. During the finishing period (weeks 11-20) of Experiment 2 the feed conversion ratio tended $(\mathrm{P}<0.10)$ to differ between treatments: feed conversion ratio for the LL and HL treatments was more favourable than that for the $\mathrm{LH}$ treatment. Feed conversion ratio for the HH treatment was intermediate, and did not differ from that of the LL, HL or LH treatments. The level of crude protein degradability appears to have no effect on calf performance during the starter period, but it may, however, be beneficial to feed finisher diets with a lower crude protein degradability during the finisher period.
\end{abstract}

Keywords: calves, nutrition, protein degradability, veal production

\# Author to whom correspondence should be addressed. E-mail: cwc@ maties.sun.ac.za

\section{Introduction}

Protein requirements of young growing calves have been studied since at least 1920 (Spitzer \& Carr, 1920). During the pre-ruminant phase, the amino acids absorbed from the small intestine are primarily derived from dietary proteins. When the consumption of solid feed increases, rumen microbial protein becomes the major source of absorbed amino acids. In the early 1960's Roy (1964) had already suggested that protein quality should be an important consideration when formulating high-concentrate diets for the transition period from pre-ruminant to ruminant. According to Ørskov (1977), microbial protein production in the early-weaned ruminant may not be sufficient to sustain maximum growth rates. These animals should respond to an increased undegradable dietary protein (UDP) supply provided that the amino acid composition of the protein is appropriate. During the transitional phase calves should therefore be supplied with degradable dietary protein to stimulate microbial protein synthesis and also with undegradable dietary protein to optimize the amino acid profile of digesta in the small intestine (Vazques-Anon et al., 1993).

Improved body weight gains in response to UDP have been reported for calves under the age of 12 weeks (Whitelaw et al., 1961; Whitelaw et al., 1963; Veen \& Vahl, 1984). More recent results, however, showed no differences in average daily gain (ADG) between diets containing different UDP levels (Trotta et al., 1984; Lalles \& Poncet, 1990). Calves older than 12 weeks and weighing up to $200 \mathrm{~kg}$ had better body weight gain (Amos, 1986) and feed efficiency (Swartz et al., 1991) when fed diets of high UDP content. The NRC (1989) recommends UDP levels of 84.7, 69.5, 57.8 and $48.4 \%$ for large breed growing male calves of 100, 150, 200 and $250 \mathrm{~kg}$ live weight, respectively. No recommendations exist for calves weighing less than $100 \mathrm{~kg}$.

This study was conducted to investigate the effect of various levels of UDP in calf starter and finisher diets on feed intake, weight gain, feed conversion efficiency and certain carcass parameters. The objective was to determine the level of dietary UDP required for young calves intended for veal production. 


\section{Materials and Methods}

\section{Experiment 1}

Twenty-four Holstein bull calves between three and seven days of age were blocked according to arrival weight, and the calves within each block were then randomly assigned to one of three treatments. The treatments consisted of diets containing a low (LD), Medium (MD) or high (HD) level of rumen degradable protein. The experiment was divided into two periods, namely the starter period (arrival until 11 weeks) and the finisher period (12-20 weeks). Diets in each period were formulated to be iso-nitrogenous and iso-caloric, but differed in dietary crude protein $(\mathrm{CP})$ degradability. The ingredient composition of the diets is presented in Table 1 and the calculated CP degradability in Table 3.

Table 1 Ingredient composition (\%) of veal calf starter and finisher diets containing low (LD), Medium (MD) or high (HD) levels of rumen degradable protein

\begin{tabular}{lrrrrrrrr}
\hline & \multicolumn{3}{c}{ Starter diet } & & \multicolumn{3}{c}{ Finisher diet } \\
\cline { 2 - 4 } \cline { 7 - 9 } Ingredient & LD & MD & HD & & LD & MD & HD \\
\hline Maize meal & 60.76 & 55.68 & 50.59 & & 73.24 & 71.17 & 69.24 \\
Fish meal & 6.07 & 3.04 & - & & 3.00 & 1.53 & - \\
Maize gluten meal (60) & 7.07 & 3.54 & - & & 3.00 & 1.53 & - \\
Sunflower oilcake & - & 11.65 & 23.30 & & - & 5.00 & 10.00 \\
Molasses & 5.07 & 5.07 & 5.07 & & 5.00 & 5.00 & 5.00 \\
Chopped lucerne hay & 15.20 & 17.74 & 20.27 & & 15.00 & 15.00 & 15.00 \\
Oat hulls & 5.07 & 2.54 & - & & - & - & - \\
Salt & 0.51 & 0.51 & 0.51 & & 0.50 & 0.50 & 0.50 \\
Mineral premix & 0.27 & 0.27 & 0.27 & & 0.27 & 0.27 & 0.27 \\
\hline
\end{tabular}

Each calf received two litres of an electrolyte solution (All-Lyte, Alltech, South Africa) for the first two feedings after arrival. The third feeding consisted of one litre of fresh milk. Thereafter calves received two litres of fresh milk twice daily for three weeks and then two litres of fresh milk once daily until weaning one week later. Calves were offered starter pellets $a d$ lib. from day seven until week 11, and finisher pellets $a d$ lib. from week 12 until week 20.

Calves were housed individually in elevated pens $(115 \times 340 \mathrm{~cm})$ with slatted wooden floors. Oat straw was used as bedding and replaced as often as needed to ensure dry bedding at all times. The pens were in a semi-closed barn with natural ventilation. Calves had free access to fresh water throughout the experiment. The calves were slaughtered at a commercial abattoir at the end of week 20. Cold carcass mass was used to calculate dressing percentage.

Two fistulated lactating Holstein cows were used to determine $12 \mathrm{~h}$ in sacco dry matter (DM) and CP degradabilities of the six diets. Diets were hammer-milled through a two $\mathrm{mm}$ screen and weighed into dacron bags $(100 \times 180 \mathrm{~mm})$ with a pore size of $53 \pm 2 \mu \mathrm{m}$. Approximately five g DM was accurately weighed into each bag, providing a sample to surface ratio of ca. $14 \mathrm{mg} / \mathrm{cm}^{2}$ to comply with standard procedures (Vanzant et al., 1998). Samples were prepared in triplicate for each diet and each cow. Bags were soaked in water $\left(39^{\circ} \mathrm{C}\right)$ for 15 minutes before rumen incubation and then placed inside a woven nylon bag to facilitate easy retrieval of all the bags. Bags were removed after $12 \mathrm{~h}$ incubation, placed in ice water to terminate fermentation, rinsed under slow running tap water and then machine-washed three times on a gentle cycle. Bags were dried at $55^{\circ} \mathrm{C}$ for $24 \mathrm{~h}$ and the residue analysed for CP content (AOAC, 1998).

\section{Experiment 2}

Thirty-two Holstein bull calves between three and ten days of age were purchased from one source, and arrived in four groups of eight each over a period of five weeks. They were weighed upon arrival and blocked according to arrival date. Each group of eight was subdivided into two groups according to birth date, and calves within an age subgroup were randomly assigned to one of four treatments. The treatments were HH (starter and finisher diet with high RDP), HL (starter diet with high RDP and finisher diet with low RDP), LH (starter diet with low RDP and finisher diet with high RDP) and LL (starter and finisher diet with low RDP). The experiment was divided into two periods of 10 weeks each. Experimental diets within each period were formulated to be isonitrogenous and iso-caloric with the largest possible difference in rumen degradable protein (RDP) content, given the available feedstuffs. The ingredient composition of the diets is presented in Table 2. 
Table 2 Ingredient composition (\%) of veal calf starter and finisher diets of low (L) and high (H) rumen degradable protein content

\begin{tabular}{|c|c|c|c|c|}
\hline \multirow[b]{2}{*}{ Ingredient } & \multicolumn{2}{|c|}{ Starter diet } & \multicolumn{2}{|c|}{ Finisher diet } \\
\hline & $\mathrm{L}$ & $\mathrm{H}$ & $\mathrm{L}$ & $\mathrm{H}$ \\
\hline Maize & 55.10 & 48.17 & 72.00 & 68.00 \\
\hline Barley & 1.73 & 5.00 & - & - \\
\hline Wheaten bran & - & 2.40 & - & - \\
\hline Chopped lucerne hay & 21.90 & 15.00 & 10.00 & 15.00 \\
\hline $\mathrm{NaOH}$-treated wheat straw & - & - & 5.00 & - \\
\hline Fishmeal & 6.77 & - & 3.00 & - \\
\hline Sunflower oilcake & - & 3.52 & - & 10.00 \\
\hline Groundnut oilcake & - & 7.50 & - & - \\
\hline Soybean oilcake & - & 9.97 & - & - \\
\hline Maize gluten meal (60) & 5.74 & - & 3.00 & - \\
\hline Bloodmeal & 0.40 & - & - & - \\
\hline Molasses & 5.00 & 5.00 & 5.00 & 5.00 \\
\hline Limestone & - & - & 1.13 & 1.13 \\
\hline Mono-calcium phosphate & 1.62 & 1.84 & - & - \\
\hline Salt & 1.23 & 1.10 & 0.37 & 0.37 \\
\hline Vitamin and mineral premix & 0.51 & 0.51 & 0.50 & 0.50 \\
\hline
\end{tabular}

Housing and feeding management were the same as described for Experiment 1. Feed samples were collected weekly throughout the trial and bulked for chemical analysis. Dry matter, ash, crude protein, ether extract and crude fibre were determined according to AOAC (1998) and ADF and NDF according to Van Soest \& Robertson (1985). Three rumen fistulated Holstein cows were used to determine $24 \mathrm{~h}$ in sacco DM and CP degradability values of the diets in order to confirm calculated degradability differences. Calves were slaughtered at a commercial abattoir at the end of week 20 and cold carcass mass was used to calculate dressing percentage.

Feed intake and body weight was recorded weekly. Body weight gain, feed intake and feed conversion efficiency data for the pre-weaning, starter, finishing and entire experimental period were analysed as a randomised block design using the GLM procedure of SAS (1996). Significance was declared at $\mathrm{P} \leq 0.05$ unless otherwise indicated. Least square means were separated using the PDIFF option when $\mathrm{P} \leq 0.05$.

\section{Results and discussion Experiment 1}

The chemical composition, calculated RDP values and $12 \mathrm{~h}$ in sacco degradability values of the six diets used in the experiment are presented in Table 3.

Table 3 Chemical composition (\% of DM), calculated RDP content (\% of CP) and measured $12 \mathrm{~h}$ in sacco degradability values of starter and finisher veal calf diets

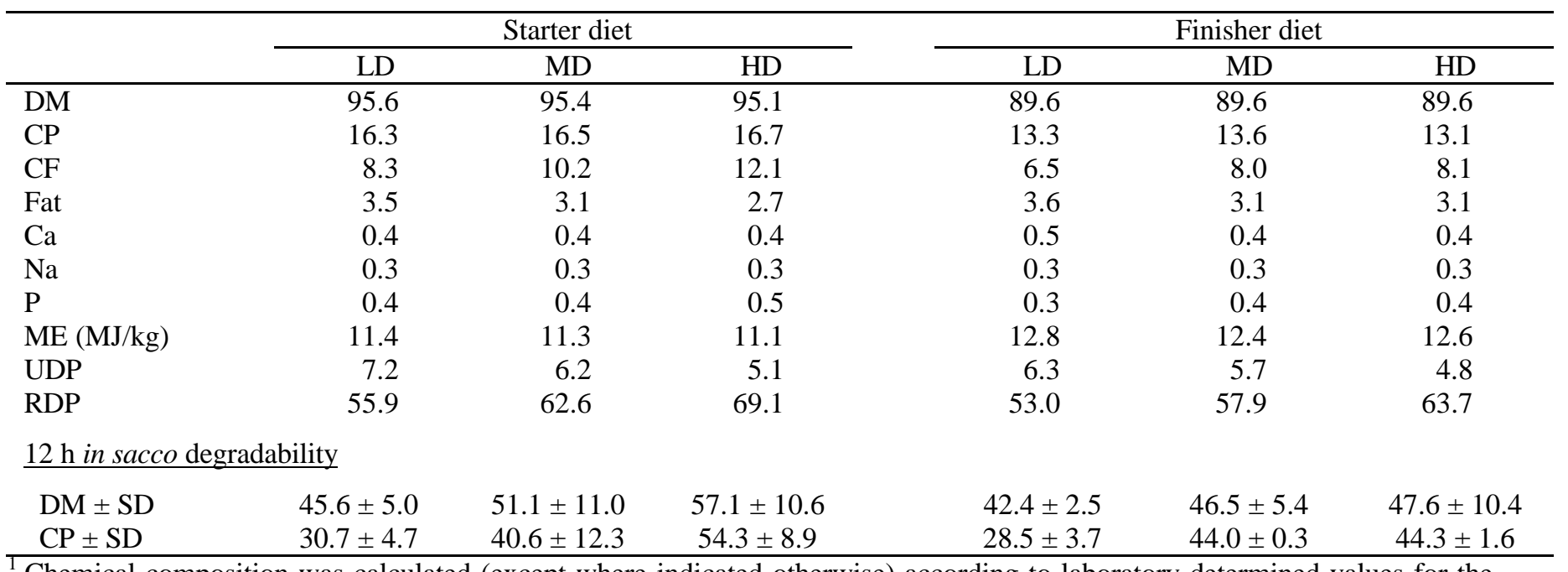

${ }^{1}$ Chemical composition was calculated (except where indicated otherwise) according to laboratory-determined values for the feedstuffs used to prepare the experimental diets. UDP: Undegradable dietary protein; RDP: Rumen degradable protein. 
The three diets fed during the starter period were of similar CP and metabolizable energy (ME) content. The slight differences in ME content between the diets were probably due to differences in fat content. In order to obtain as large a difference as possible in RDP content, the HD starter diet contained a large amount of sunflower oilcake which has a much higher RDP content than fish meal or maize gluten meal, viz. $86 \%$ vs. 40 or $31 \%$ respectively (Erasmus \& Prinsloo, 1988). The high sunflower oilcake content resulted in a higher crude fibre content. The CP degradability values determined by the in sacco procedure were much lower than the calculated values. This is due to the fact that the calculated values were based on average effective degradability estimates for the individual ingredients (literature values), while the in sacco values were $12 \mathrm{~h}$ degradability values for the actual diets. The CP and DM degradabilities do, however, confirm that the diets were indeed of low, medium and high degradable CP content. The finisher diets were of similar CP and ME content, but the crude fibre content of the LD diet was lower than that of the other two diets due to the absence of sunflower oilcake meal in the LD diet. The extent of the difference was smaller than that between the starter diets because of the lower sunflower oilcake content in the HD finisher diet. The calculated RDP content (Table 3) indicates moderate differences between the three finisher diets. The limited availability of feedstuffs in the Western Cape precluded the formulation of finisher diets with a greater difference in RDP content. The measured in sacco RDP content of all three diets was lower than the calculated values. There were no appreciable differences in DM or CP degradability between the MD and HD diets. The reason for these discrepancies can be partly attributed to the high level of variance as seen in the large standard deviations, especially in the case of the DM degradability of the HD diet (Table 3). Another reason may be the use of average RDP values for feedstuffs for formulating the diets, as degradability can differ quite substantially between different batches of the same feedstuff (Erasmus \& Prinsloo, 1988). Body weight, feed intake and carcass parameters for individual periods and the entire experimental period are presented in Table 4.

Table 4 Feed intake, body weight gain, feed conversion ratio and carcass parameters for veal calves receiving diets differing in RDP content

\begin{tabular}{|c|c|c|c|c|c|}
\hline \multirow[b]{2}{*}{ Item } & \multicolumn{3}{|c|}{ Treatment } & \multirow[b]{2}{*}{ SEM } & \multirow[b]{2}{*}{$\mathrm{P}$} \\
\hline & $\mathrm{LD}$ & MD & $\mathrm{HD}$ & & \\
\hline \multicolumn{6}{|l|}{ Weeks $0-4$} \\
\hline$\overline{\text { Total intake }^{1}}(\mathrm{~kg})$ & 20.80 & 21.00 & 20.43 & 1.0075 & 0.9213 \\
\hline Dry matter intake (kg/day) & 0.74 & 0.75 & 0.73 & 0.0360 & 0.9213 \\
\hline Total gain $(\mathrm{kg})$ & 10.88 & 12.30 & 11.53 & 1.5470 & 0.8121 \\
\hline Average daily gain ( $\mathrm{kg} /$ day $)$ & 0.39 & 0.44 & 0.41 & 0.0552 & 0.8121 \\
\hline FCR (kg intake/kg gain) & 2.02 & 2.03 & 1.90 & 0.2694 & 0.9363 \\
\hline \multicolumn{6}{|l|}{ Weeks $0-11$} \\
\hline Total intake $^{1}(\mathrm{~kg})$ & 110.06 & 117.94 & 115.96 & 5.5303 & 0.5953 \\
\hline Dry matter intake (kg/day) & 1.43 & 1.53 & 1.51 & 0.0718 & 0.5953 \\
\hline Total gain $(\mathrm{kg})$ & 49.46 & 55.51 & 49.77 & 3.4929 & 0.4412 \\
\hline Average daily gain ( $\mathrm{kg} / \mathrm{day})$ & 0.64 & 0.72 & 0.65 & 0.0454 & 0.4412 \\
\hline FCR (kg intake/kg gain) & 2.27 & 2.14 & 2.34 & 0.0919 & 0.3648 \\
\hline \multicolumn{6}{|l|}{ Weeks 12-20 } \\
\hline$\overline{\text { Total intake }(\mathrm{kg})}$ & 219.60 & 221.48 & 229.78 & 5.4842 & 0.3799 \\
\hline Dry matter intake (kg/day) & 3.49 & 3.52 & 3.65 & 0.0855 & 0.3797 \\
\hline Total gain $(\mathrm{kg})$ & $73.18^{\mathrm{a}}$ & $65.30^{\mathrm{ab}}$ & $63.05^{\mathrm{b}}$ & 3.0209 & 0.0736 \\
\hline Average daily gain ( $\mathrm{kg} / \mathrm{day})$ & $1.16^{\mathrm{a}}$ & $1.04^{\mathrm{ab}}$ & $1.00^{\mathrm{b}}$ & 0.0480 & 0.0736 \\
\hline FCR (kg intake/kg gain) & $3.03^{\mathrm{a}}$ & $3.45^{\mathrm{b}}$ & $3.70^{\mathrm{b}}$ & 0.1500 & 0.0205 \\
\hline \multicolumn{6}{|l|}{ Weeks 0-20 } \\
\hline$\overline{\text { Total intake }}^{1}(\mathrm{~kg})$ & 323.44 & 334.20 & 339.65 & 9.7120 & 0.4908 \\
\hline Dry matter intake (kg/day) & 2.31 & 2.39 & 2.43 & 0.0694 & 0.4908 \\
\hline Total gain $(\mathrm{kg})$ & 122.64 & 120.81 & 112.82 & 4.7528 & 0.3199 \\
\hline Average daily gain ( $\mathrm{kg} /$ day $)$ & 0.88 & 0.86 & 0.81 & 0.0340 & 0.3200 \\
\hline FCR (kg intake/kg gain)* & $2.65^{\mathrm{a}}$ & $2.78^{\mathrm{a}}$ & $3.03^{\mathrm{b}}$ & 0.0602 & 0.0020 \\
\hline Carcass mass & 85.63 & 82.76 & 79.75 & 2.3447 & 0.2308 \\
\hline Dressing percentage & 49.38 & 49.11 & 48.69 & 0.6483 & 0.7422 \\
\hline
\end{tabular}

Total intake includes dry matter milk intake. ${ }^{a, b}$ Means within a row without common superscripts differ significantly $(\mathrm{P}<$ $0.05)$. ${ }^{*} \mathrm{HD}$ and LD differ significantly $(\mathrm{P}<0.001)$. FCR: Feed conversion ratio; RDP $=$ Rumen degradable protein. 
Feed intake, body weight gain and feed efficiency did not differ between treatments during the pre-weaning period (weeks 0-4). According to Veen \& Vahl (1984) the degree of protein degradability does not become a limiting factor until rumen function is sufficiently developed. Some reports suggest that early weaning stimulates the development of rumen function. Rumen ammonia nitrogen concentration, total volatile fatty acid concentration and the contribution of microbial nitrogen to total nitrogen in abomasal contents resembled that of mature ruminants as soon as a week after early weaning (Quigley et al., 1985; Anderson et al., 1987a,b). However, Funaba et al. (1994) suggested that the digestion of solid feed in the rumen might not fully meet the nutrient demands of calves because of the immature size of the rumen.

Feed intake and body weight gain during the starter period (weeks 0-11) followed the same trend as observed in the pre-weaning period. Bouchard et al. (1980) replaced soybean meal (SBM) with meat and bone meal (MBM) in concentrate diets for veal calves and reported no significant difference in concentrate intake or feed conversion ratio (FCR) between treatments. Fiems et al. (1987) found no effect when replacing SBM with formaldehydetreated SBM as the sole nitrogen source in starter diets for calves weighing less than $150 \mathrm{~kg}$. The nitrogen degradability of the SBM diet was $89.9 \%$ and that of the treated SBM diet was $68.0 \%$. The treated SBM improved ADG slightly, but feed intake also increased resulting in a similar FCR for the two treatments.

Treatment had no effect on feed intake during the finishing period (weeks 12-20). Total gain and ADG for the LD treatment was higher than for the HD treatment $(\mathrm{P}=0.03)$. Body weight gain for the MD treatment was intermediate, but did not differ from that for the LD $(P=0.10)$ or $\mathrm{HD}(\mathrm{P}=0.62)$ treatments. FCR for the LD treatment was significantly better than for the MD and HD treatments. The more efficient FCR resulted from the higher body weight gain of calves in the LD treatment. In a trial with 4-month-old Holstein heifers, Amos (1986) found that an increase in UDP increased ADG, with no difference in feed intake or FCR. Swartz et al. (1991) reported lower daily DM intakes for high (37.9\%) and low (29.7\%) UDP levels compared to an intermediate level (33.8\%) for calves aged 14-25 weeks. In their experiment FCR improved with increasing UDP content, but ADG did not differ between treatments. Feed intake and body weight gain over the total experimental period followed the same trend as during the finishing period. Only FCR differed significantly between treatments when calculated over the entire period. Both the LD and MD treatment resulted in a better FCR than the HD treatment. Carcass mass and dressing percentage did not differ between treatments.

\section{Experiment 2}

The chemical composition of the diets used in Experiment 2 is presented in Table 5. The only difference in chemical composition between the diets was in terms of RDP content. The $24 \mathrm{~h}$ in sacco degradability values confirmed that the diets were either of low or high RDP content.

Table 5 Chemical composition (\% of DM), calculated RDP content (\% of CP) and measured $24 \mathrm{~h}$ in sacco degradability values of starter and finisher veal calf diets

\begin{tabular}{|c|c|c|c|c|c|}
\hline \multirow[b]{2}{*}{ Item } & & \multicolumn{2}{|c|}{ Starter diet } & \multicolumn{2}{|c|}{ Finisher diet } \\
\hline & & $\mathrm{L}$ & $\mathrm{H}$ & $\mathrm{L}$ & $\mathrm{H}$ \\
\hline \multirow[t]{7}{*}{ Determined: } & DM & 90.7 & 91.1 & 89.2 & 89.0 \\
\hline & Ash & 7.4 & 7.0 & 7.0 & 6.8 \\
\hline & $\mathrm{CP}$ & 19.2 & 19.3 & 13.1 & 13.4 \\
\hline & $\mathrm{CF}$ & 6.9 & 6.8 & 7.3 & 9.0 \\
\hline & NDF & 24.9 & 22.0 & 22.3 & 22.8 \\
\hline & $\mathrm{ADF}$ & 10.7 & 9.7 & 12.2 & 14.1 \\
\hline & Ether extract & 3.8 & 3.4 & 3.7 & 3.5 \\
\hline \multirow[t]{6}{*}{ Calculated: $^{1}$} & $\mathrm{Ca}$ & 1.1 & 0.9 & 0.9 & 0.9 \\
\hline & $\mathrm{Na}$ & 0.4 & 0.3 & 0.4 & 0.3 \\
\hline & $\mathrm{P}$ & 0.7 & 0.8 & 0.4 & 0.4 \\
\hline & ME (MJ/kg) & 12.2 & 12.2 & 12.9 & 12.7 \\
\hline & UDP & 9.2 & 6.6 & 5.8 & 4.2 \\
\hline & $\mathrm{RDP}(\%$ of $\mathrm{CP})$ & 52.0 & 65.6 & 55.7 & 68.4 \\
\hline \multicolumn{6}{|c|}{$24 \mathrm{~h}$ in sacco degradability } \\
\hline \multirow{2}{*}{\multicolumn{2}{|c|}{$\begin{array}{l}\mathrm{DM} \pm \mathrm{SD} \\
\mathrm{CP} \pm \mathrm{SD}\end{array}$}} & $83.1 \pm 1.0$ & $90.9 \pm 0.3$ & $82.0 \pm 1.4$ & $85.2 \pm 1.1$ \\
\hline & & $68.6 \pm 1.3$ & $94.7 \pm 0.8$ & $73.7 \pm 1.0$ & $90.5 \pm 1.6$ \\
\hline
\end{tabular}

${ }^{1}$ Chemical composition was calculated according to laboratory determined values for the batches of feedstuffs used to prepare the experimental diets. 
Body weight, feed intake and carcass parameters for the different experimental periods are presented in Table 6. Treatment had no effect on feed intake, weight gain or feed conversion efficiency in the pre-weaning period (weeks 0-4). Feed intake and body weight gain results for the starter period (weeks 0-10) followed the same trends as those for the pre-weaning period. These results confirm the conclusion from Experiment 1, viz. that no significant advantage appears to be gained from feeding a diet low in degradable protein to calves under 10 weeks of age. In a trial with Holstein calves receiving one of three diets differing in UDP content, Swartz et al. (1991) also found no differences in feed intake, ADG or FCR during the first 12 weeks of age. They attributed the lack of growth differences to the fact that feed was offered $a d$ lib., which allowed calves to consume protein and energy in excess of NRC (1989) recommendations. Veen \& Vahl (1984) did, however, find differences in FCR between diets with either slowly or rapidly degradable protein. The $12 \mathrm{~h}$ in sacco nitrogen degradability of the slowly degradable diet was $35 \%$ of CP and that of the rapid degradable diet $62 \%$. In two of their three trials the slowly degradable diet had a more favourable FCR for calves 3-7 weeks of age. Live weight gains were slightly higher for the slowly degradable diet, but only significantly so in one trial for the period 7-12 weeks of age. They concluded, contrary to observations from the current experiment, that growth of young calves can be improved if a higher than average proportion of the ration protein is not degraded in the rumen.

Table 6 Feed intake, weight gain, feed conversion efficiency and carcass parameters for veal calves receiving diets differing in RDP content

\begin{tabular}{|c|c|c|c|c|c|c|}
\hline & \multicolumn{4}{|c|}{ Treatment } & \multirow[b]{2}{*}{ SEM } & \multirow[b]{2}{*}{$\mathrm{P}$} \\
\hline & \multicolumn{2}{|c|}{$\mathrm{L}$} & \multicolumn{2}{|c|}{$\mathrm{H}$} & & \\
\hline \multicolumn{7}{|l|}{ Weeks $0-4$} \\
\hline Total intake $(\mathrm{kg})$ & \multicolumn{2}{|c|}{20.27} & \multicolumn{2}{|c|}{19.22} & 0.9323 & 0.4368 \\
\hline Dry matter intake (kg/day) & \multicolumn{2}{|c|}{0.72} & \multicolumn{2}{|c|}{0.69} & 0.0333 & 0.4369 \\
\hline Total gain $(\mathrm{kg})$ & \multirow{2}{*}{\multicolumn{2}{|c|}{$\begin{array}{r}10.03 \\
0.36\end{array}$}} & \multicolumn{2}{|c|}{9.09} & 1.1431 & 0.5676 \\
\hline Average daily gain ( $\mathrm{kg} / \mathrm{day})$ & & & & & 0.0408 & 0.5675 \\
\hline FCR (kg intake/kg gain) & \multicolumn{2}{|c|}{2.26} & \multicolumn{2}{|c|}{$\begin{array}{l}0.32 \\
2.81\end{array}$} & 0.3410 & 0.2668 \\
\hline \multicolumn{7}{|l|}{ Weeks $0-10$} \\
\hline$\overline{\text { Total intake }}(\mathrm{kg})$ & \multicolumn{2}{|c|}{105.13} & \multicolumn{2}{|c|}{102.63} & 4.0763 & 0.6695 \\
\hline Dry matter intake $(\mathrm{kg} /$ day $)$ & \multicolumn{2}{|c|}{1.50} & \multicolumn{2}{|c|}{1.47} & 0.0582 & 0.6694 \\
\hline Total gain $(\mathrm{kg})$ & \multicolumn{2}{|c|}{47.25} & \multicolumn{2}{|c|}{44.66} & 2.0321 & 0.3761 \\
\hline Average daily gain ( $\mathrm{kg} / \mathrm{day})$ & \multicolumn{2}{|c|}{0.67} & \multicolumn{2}{|c|}{0.64} & 0.0290 & 0.3761 \\
\hline \multirow{2}{*}{ FCR (kg intake/kg gain) } & \multicolumn{2}{|c|}{2.24} & \multicolumn{2}{|c|}{2.33} & 0.0534 & 0.2518 \\
\hline & LL & LH & $\mathrm{HL}$ & $\mathrm{HH}$ & & \\
\hline \multicolumn{7}{|l|}{$\underline{\text { Weeks } 11-20}$} \\
\hline$\overline{\text { Total intake }(\mathrm{kg})}$ & 295.11 & 302.63 & 298.36 & 290.64 & 11.1340 & 0.8901 \\
\hline Dry matter intake (kg/day) & 4.22 & 4.32 & 4.26 & 4.15 & 0.1591 & 0.8901 \\
\hline Total gain $(\mathrm{kg})$ & 90.00 & 84.56 & 91.44 & 88.13 & 2.9246 & 0.3980 \\
\hline Average daily gain (kg/day) & 1.29 & 1.21 & 1.31 & 1.26 & 0.0418 & 0.3980 \\
\hline FCR (kg intake/kg gain) & $3.29^{\mathrm{a}}$ & $3.61^{\mathrm{b}}$ & $3.27^{\mathrm{a}}$ & $3.31^{\mathrm{ab}}$ & 0.1040 & 0.0984 \\
\hline \multicolumn{7}{|l|}{ Weeks $0-20$} \\
\hline Total intake $(\mathrm{kg})$ & 400.13 & 405.36 & 398.11 & 393.42 & 16.2566 & 0.9633 \\
\hline Dry matter intake (kg/day) & 2.86 & 2.90 & 2.84 & 2.81 & 0.1161 & 0.9633 \\
\hline Total gain $(\mathrm{kg})$ & 138.31 & 130.75 & 135.31 & 133.56 & 5.2347 & 0.7778 \\
\hline Average daily gain ( $\mathrm{kg} / \mathrm{day})$ & 0.99 & 0.93 & 0.97 & 0.95 & 0.0374 & 0.7778 \\
\hline FCR (kg intake/kg gain) & $2.90^{\mathrm{a}}$ & $3.11^{\mathrm{b}}$ & $2.95^{\mathrm{ab}}$ & $2.96^{\mathrm{ab}}$ & 0.0699 & 0.1818 \\
\hline Carcass mass & 92.94 & 90.31 & 93.69 & 91.44 & 2.8147 & 0.8332 \\
\hline Dressing percentage & 51.33 & 51.36 & 51.92 & 51.74 & 0.4919 & 0.7874 \\
\hline
\end{tabular}

FCR = Feed conversion ratio; RDP $=$ Rumen degradable protein. ${ }^{\text {a,b }}$ Means within a row without common superscripts differ significantly $(\mathrm{P}<0.05)$.

Feed intake and body weight gain during the finishing period did not differ between treatments. Cummins et al. (1982) found that nitrogen degradability had no effect on feed intake, ADG or feed efficiency in Holstein bull calves (8-20 weeks of age). In our experiment FCR during the finishing period tended to differ between treatments. Calves receiving the LL and HL treatments had a more favourable FCR than calves receiving the LH treatment (P $=0.04$ and $\mathrm{P}=0.03$ respectively). Calves receiving the $\mathrm{HH}$ treatment had a FCR comparable to those receiving the 
HL and LL treatments, and tended to have a more favourable FCR than those receiving the LH treatment $(\mathrm{P}=$ 0.06). Cummins et al. (1982) suggested that either high bypass of dietary protein or high degradability of nitrogen, and thus possibly greater microbial protein synthesis, results in the delivery of higher quality protein to the small intestine. According to Tamminga (1979), an inadequate supply of degradable protein in the rumen could decrease microbial efficiency and impact negatively on feed efficiency. A possible combination of a greater microbial protein synthesis for the HH treatment with a lower microbial efficiency for the LL and HL treatments could explain the lack of difference in FCR between these treatments.

It is not clear why the FCR of the LH treatment was less favourable than that of the other three treatments during the finishing period of Experiment 2. Swartz et al. (1991) suggested that protein sources that are of low degradability might not provide sufficient nitrogen in the rumen to achieve maximum microbial growth. It is possible that calves that received the low degradability diet during the starter period did not have the same rumen microbial population (qualitatively and quantitatively) as calves receiving the high degradability starter diet. Calves that received the high degradability finisher diet may therefore have needed an adaptation period for the rumen microbial population to increase. It is, however, unlikely that this adaptation period would have lasted longer than two weeks. It is also unlikely that the first two weeks of the finishing period would have had such an effect on the whole 10 week period. Feed intake and body weight gain for the whole experimental period followed the same trend as that for the finishing period. The FCR of calves receiving the LL treatment was significantly better than that of calves receiving the LH treatment $(\mathrm{P}=0.04)$, but was comparable to that for the $\mathrm{HL}$ and $\mathrm{HH}$ treatments. As in Experiment 1, the carcass mass and dressing percentage were similar for all treatments. The results from Experiment 2 confirm those of Experiment 1 in that a diet relatively high in RDP seems adequate for calves in the starter period. The benefit of supplying protein sources higher in UDP could only be observed in the finishing period.

\section{Conclusion}

Results from these two experiments suggest that the level of CP degradability in starter diets has no effect on pre-weaning calf performance. Results furthermore suggest that young calves up to 10 weeks of age may not utilize RDP in the same way as mature ruminants. Calves with a live weight of less than $100 \mathrm{~kg}$ may still have suboptimal rumen function, and it seems possible for potentially highly degradable protein to escape from the rumen intact. Provided therefore that calves are allowed to consume starter diets ad lib., and that the CP content of starter diets meets generally accepted recommendations, it seems possible for them to consume enough dry matter to supply their needs for rapid growth from highly degradable protein sources. According to our results CP degradability, however, appears to have an effect on feed conversion ratio during the finishing period. An additional supply of UDP from 11-20 weeks of age (bodyweight of $\pm 100 \mathrm{~kg}$ to $\pm 200 \mathrm{~kg}$ ) appears to be warranted.

\section{References}

Amos, H.E., 1986. Influence of dietary protein degradability and energy concentration on growth of heifers and steers and intraruminal protein metabolism. J. Dairy Sci. 69, 2099.

Anderson, K.L., Nagaraja, T.G. \& Morrill, J.L., 1987a. Ruminal metabolic development in calves weaned conventionally or early. J. Dairy Sci. 70, 1000.

Anderson, K.L., Nagaraja, T.G., Morrill, J.L., Avery, T.B., Galitzer, S.J. \& Boyer, J.E., 1987b. Ruminal microbial development in conventionally or early-weaned calves. J. Anim. Sci. 64, 1215.

AOAC, 1998. Official Methods of Analysis $\left(16^{\text {th }}\right.$ ed.). Association of Official Analytical Chemists, Washington, DC.

Bouchard, R., Laflamme, L.F., Lachance, B. \& Roy, G.L., 1980. Levels of protein and fat and type of protein in vealer rations. Can. J. Anim. Sci. 60, 523.

Cummins, K.A., Nocek, J.E. \& Polan, C.E., 1982. Growth and nitrogen balance of calves fed rations of varying nitrogen degradability and physical form. J. Dairy Sci. 65, 773.

Erasmus, L.J. \& Prinsloo, J., 1988. The establishment of a protein degradability data base for dairy cattle using the nylon bag technique. 1. Protein sources. S. Afr. J. Anim. Sci. 18, 23.

Fiems, L.O., Cottyn, B.G., Boucque, Ch.V. \& Buysse, F.X., 1987. Effect of formaldehyde-treated soybean meal and urea in starters on nitrogen quality, degradability in sacco, sheep digestibility and calf performance. Anim. Feed Sci. \& Techn. 16, 287.

Funaba, M., Kagiyama, K., Iriki, T. \& Abe, M., 1994. Changes in nitrogen balance with age in calves weaned at 5 or 6 weeks of age. J. Anim. Sci. 72, 732.

Lalles, J.P. \& Poncet, C., 1990. Changes in ruminal and intestinal digestion during and after weaning in dairy calves fed concentrate diet containing pea or soybean meal. 1. Digestion of organic matter and nitrogen. 
Livest. Prod. Sci. 24, 129.

National Research Council., 1989. Nutrient Requirements of Dairy Cattle. (6 $6^{\text {th }}$ rev. edition). Natl. Acad. Sci., Washington, DC.

Oldham, J.D. \& Smith, T., 1982. Protein-energy interrelationships for growing and for lactating cattle. In: Protein contribution of feedstuffs for ruminants. E.L. Miller, I.H. Pike and A.J.H. Van Es (ed.). Butterworths, London.

Ørskov, E.R., 1977. Capacity for digestion and effects of composition of absorbed nutrients on animal metabolism. J. Anim. Sci. 46, 600.

Quigley, J.D., III, Schwab, C.G. \& Hylton, W.E., 1985. Development of rumen function in calves: nature of protein reaching the abomasum. J. Dairy Sci. 68, 694.

Roy, J.H.B., Gaston, H.J., Shillam, K.W.G., Thompson, S.Y., Stobo, I.J.F. \& Greatorex, J.C., 1964. The nutrition of the veal calf. The effect of anaemia and of iron and chlortetracycline supplementation on the performance of calves given large quantities of whole milk. Br. J. Nutr. 18, 467.

SAS., 1996. SAS User's Guide: Statistics, Version 6.12. SAS Inst., Inc., Cary, NC.

Spitzer, G. \& Carr, R.H., 1920. The efficiency of milk substitutes in calf feeding. J. Dairy Sci. 3, 315.

Swartz, L.A., Heinrichs, A.J., Varga, G.A. \& Muller, L.D., 1991. Effects of varying dietary undegradable protein on dry matter intake, growth, and carcass composition of Holstein calves. J. Dairy Sci. 74, 3884.

Tamminga, S., 1979. Protein degradation in the forestomachs of ruminants. J. Anim. Sci. 49, 1615.

Trotta, A.P., Kesler, E.M. \& Hargrove, G.L., 1984. Percent and solubility of protein in complete feeds for Holstein calves to age 12 weeks. J. Dairy Sci. 67, 2560.

Van Soest, P.J. \& Robertson, J.B., 1985. Analysis of Forage and Fibrous Feeds. A Laboratory Manual. Cornell Univ., Ithaca, NY.

Vanzant, E.S., Cochran, R.C. \& Titgemeyer, E.C., 1998. Standardization of in situ techniques for ruminant feedstuffs evaluation. J. Anim. Sci. 76, 2717.

Vazques-Anon, M., Heinrichs, A.J., Aldrich, J.M. \& Varga, G.A., 1993. Postweaning age effects on rumen fermentation end-products of digesta kinetics in calves weaned at 5 weeks of age. J. Dairy Sci. 76, 2742.

Veen, W.A.G. \& Vahl, H.A., 1984. The influence of the degradability of concentrate protein in the rumen and of the lysine content of the concentrate on growth and feed efficiency in early-weaned calves. Neth. J. Agric. Sci. 32, 107.

Whitelaw, F.G., Preston, T.R. \& Dawson, G.S., 1961. The nutrition of the early-weaned calf. II. A comparison of commercial groundnut meal, heat-treated groundnut meal and fish meal as the major protein source in the diet. Anim. Prod. 3, 127.

Whitelaw, F.G., Preston, T.R. \& MacLeod, N.A., 1963. The nutrition of the early-weaned calf. V. The effect of protein quality, antibiotics and level of feeding on growth and feed conversion. Anim. Prod. 5, 227. 